\section{'Valprize': A Butterhead Lettuce Cultivar for Southern Texas}

\author{
P.W. Leeper ${ }^{1}$ and B. Scully ${ }^{2}$ \\ Texas A\&M University Research Center, Weslaco, TX 78596-8399
}

Additional index words. premature bolting, downy mildew, Lactuca sativa, tipburn, pedigree breeding

Lettuce production in the Lower Rio Grande Valley (LRGV) of southern Texas has fluctuated from a high of 1882 ha in 1979 to a low of 564 ha in 1986. Since 1986, production has rebounded to just $>1000$ ha in 1989 90 season, with mostly crisphead type cultivars. There are three planting periods: midSeptember to early October; mid-October to mid-November; and late November to midDecember. Each planting period requires specifically adapted cultivars to maintain shipments from November through April. Butterhead types are occasionally integrated into the cropping system, but often fail to produce a salable product because of diseases and bolting.

The purpose of our breeding program was to develop a larger butterhead lettuce adapted to the LRGV. Primary importance was placed on resistance to premature bolting and tipbum. Secondary emphasis focused on resistance to Texas races 5 and 6 of downy mildew (Bremia lactucae Regl.), which is a sporadic problem in the region. An additional objective was to enlarge the array of adapted lettuce cultivars available to growers in southern Texas. 'Valprize' was developed as a re-

Received for publication 7 Feb. 1991. TAES Technical Article no. 27004. This research was supported in part by the South Texas Lettuce Committee. We thank Oswaldo E. Ochoa, Dept. of Vegetable Crops, Univ. of California, Davis, for evaluation of resistance to downy mildew pathotypes. The cost of publishing this paper was defrayed in part by the payment of page charges. Under postal regulations, this paper therefore must be hereby marked advertisement solely to indicate this fact.

${ }^{1}$ Professor Emeritus.

${ }^{2}$ Assistant Professor. Current address: Everglades Research and Education Center, Inst. of Food and Agricultural Sciences, Univ. of Florida, Belle Glade, FL 33430-8003. placement for 'Dark Green Boston', and butterhead lettuce periodically grown in the middle and, occasionally, late planting periods.

\section{Origin}

'Valprize' was developed by a combination of bulk and pedigree breeding that included two hybridizations (Fig. 1). The first cross was made in 1961 with 'Primaverde', a horticulturally acceptable crisphead type, as the female parent and Weslaco breeding line 210-9 S60/61 as the male parent. Line 210-9 S60/61 was selected for two generations from U.S. Dept. of Agriculture (USDA) breeding line 46696-4 (T.W. Whitaker, personal communication). Individual plant selection was practiced on the progeny of this cross until $\mathrm{F}_{7}$, when $615-\mathrm{S} 67 / 68$ was identified. This breeding line was horticulturally desirable but lacked resistance to the Texas races of downy mildew (Jones and Leeper, 1971; Sleeth and Leeper, 1966). Downy mildew resistance was transferred from 'Boettneruv', a white-seeded butterhead lettuce with yellowish-green leaves. 'Boettneruv' was introduced from Czechoslovakia in 1958 as PI 250425 (D.M. Stout, personal communication). PI 250425 was selected for downy mildew resistance and horticultural type over four generations, with breeding line 635-S67/68 identified in 1967. Boston when grown in four site/year environments. the four test environments due to premature bolting.
The second cross, between lines 635-S67/ 68 and 615-S67/68, was followed by singleplant pedigree selection through the $\mathrm{F}_{7}$ generation (Fig. 1), when line B271M was identified as resistant to downy mildew. B271M was carried forward as an unselected bulk population until $F_{11}$, when single plants were again selected and field tested in the $F_{12}$ and subsequent generations. 'Valprize' was derived from a horticulturally acceptable $F_{12}$ individual selected from the $F_{11}$ bulk population YT-40 and evaluated in four site/year environment

\section{Description}

'Valprize' is a butterhead lettuce with larger, rounder heads and darker green leaves

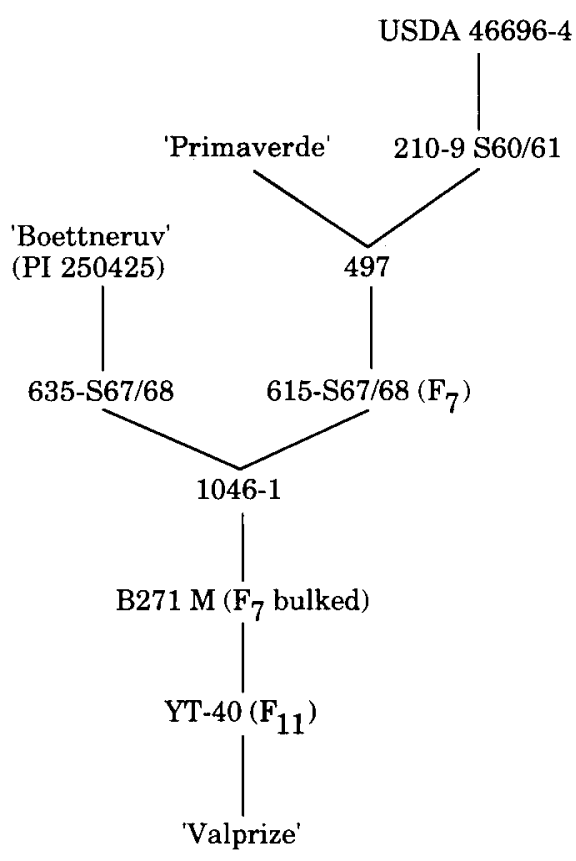

Fig. 1. Pedigree of 'Valprize', a butterhead lettuce cultivar.

Table 1. Comparison of economic traits of 'Valprize' lettuce to the standard cultivar Dark Green

\begin{tabular}{lccc}
\hline \hline Cultivar & $\begin{array}{c}\text { Mean yield } \\
\left(\mathrm{t} \cdot \mathrm{ha}^{-1}\right)\end{array}$ & $\begin{array}{c}\text { Mean head wt } \\
(\mathrm{g})\end{array}$ & $\begin{array}{c}\text { Mean stem width } \\
(\mathrm{cm})\end{array}$ \\
\hline Valprize & $14.93 \pm 3.11$ & $553 \pm 116$ & $3.3 \pm 0.27$ \\
Dark Green Boston & & 367 & 1.9 \\
\hline
\end{tabular}

“Valprize' means include SE, but 'Dark Green Boston' failed to produce marketable yields in three of 
than 'Dark Green Boston'. Average head weight exceeds $0.5 \mathrm{~kg}$ in the LRGV, and stems are wider than those of the Boston type (Table 1). Outer leaves are 15 to $20 \mathrm{~cm}$ longand 10 to $13 \mathrm{~cm}$ wide, obovate to oblanceolate with a rounded apex. Leaf midribs are straight with a mildly crinkled and somewhat undulate blade. Leaf margins have irregular serrulations 1 to $3 \mathrm{~cm}$ long. Leaf thickness, texture, and flavor, as judged by us, are equivalent to 'Dark Green Boston'. Seeds are white.

When evaluated over four environments, $50 \%$ of 'Valprize' bolted at only one site, while $100 \%$ of 'Dark Green Boston' bolted at three sites and produced no salable product. Resistance to premature bolting enables earlier planting and extends the growing season and harvest period for a given planting. 'Valprize' had little or no tipburn in these environments, while the Boston type was susceptible.

'Valprize' carries resistance to the common races of downy mildew found in Texas,
California pathotype Ia (isolate C83E11), and European race CG1, but was susceptible to California pathotypes II (isolate C83P24) and III (C83M47) and European races CS9 and SF 5. Mixed reactions resulted from inoculations with European races SF 3 and CS 12 (O.E. Ochoa, personal communication). Resistance is putatively conferred by $\mathrm{Dm} 5 / 8$ and Dm6 (Illot et al., 1987; Johnson et al., 1978; Jones and Leeper, 1971; Zink and Duffus, 1969). Yield of 'Valprize' was higher than that of 'Dark Green Boston', but comparison is difficult because of routine crop failures of the standard cultivar (Table 1). However, these results do indicate that 'Valprize' enlarges the production environment for butterhead lettuce.

\section{Availability}

Foundation seed was distributed to 10 seed companies and deposited with the Foundation Seed-Service of Texas A\&M Univ., College Station, TX 77843. Breeder's seed has also been deposited in the USDA lettuce collection held in Salinas, Calif.

\section{Literature Cited}

Blot, T.W., M.E. Durgan, and R.W. Michelmore. 1987. Genetics of virulence in Californian populations of Bremia lactucue (lettuce downy mildew). Phytopathology 77:1381-1386.

Johnson, A.G., S.A. Laxton, I.R. Crute, P.L. Gordon, and J.M. Norwood. 1978. Further work on genetics of race specific resistance in lettuce (Lactuca sativa) to downy mildew (Bremia lactucae). Ann. Applied Biol. 82:257-264.

Jones, B.L. and P.W. Leeper. 1971. Sources of immunity from races 5 and 6 of lettuce downy mildew (Bremia lactucae). Plant Dis. Rptr. 55:794-796.

Sleeth, B. and P.W. Leeper. 1966. Mildew resistant lettuce susceptible to a new physiologic race of Bremia lactucae in south Texas. Plant Dis. Rptr. 50:460.

Zink, F.W. and J.E. Duffis. 1969. Relationship of turnip mosaic virus susceptibility and downy mildew (Bremia lactucae) resistance in lettuce. J. Amer. Soc. Hort. Sci. 94:403-407. 